\title{
Effect of Torrefaction on Physio-Chemical Properties of Paddy Straw and its Size Reduction
}

\author{
Swapnaja K. Jadhav ${ }^{1}$, H. Wakudkar ${ }^{1}$, Manvendra Bhardwaj ${ }^{1}$ and Rajesh Soni ${ }^{2}$ \\ ${ }^{1}$ ICAR-Central Institute of Agricultural Engineering, Bhopal-462038, India \\ ${ }^{2}$ Department of Agricultural Engg and Technology, Punjab Agricultural University, \\ Ludhiana, Punjab-141027, India \\ *Corresponding author
}

\section{A B S T R A C T}

\begin{tabular}{|l|}
\hline Ke y w o r d s \\
Torrefaction, \\
Physiochemical \\
properties, cutting \\
force, energy \\
consumption, \\
Paddy straw
\end{tabular}

Paddy straw is one of the major agriculture waste produced in India. Burning of paddy straw is one of the easy options for farmers due to its difficult handling which produces environmental problem generating greenhouse gases. Size reduction of paddy straw is necessary for almost it's every possible utilization for biofuel production. Torrefaction mainly used to process lignocellulosic biomass that makes them easily cut, chop or grind. Torrefaction was carried out at $250^{\circ} \mathrm{C}$ for 20 and 30 minutes and compared its effect on energy requirement for size reduction with that of raw paddy straw. In this study, effect of torrefaction on physiochemical properties were evaluated in terms of proximate analysis, calorific value, mass yield, energy yield and cutting force of torrefied and untorrefied paddy straw. Cutting force of untreated paddy straw was measured as 2.18 $\mathrm{kg}$ using texture analyzer while paddy straw after torrefaction for 20 minutes and 30 minutes was 1.31 and $0.44 \mathrm{~kg}$ respectively.

\section{Introduction}

Crop residue is a major and never ending biomass source. Leaving crop residue in the field is not affordable as it's burning or decomposition is a source of green house gases like $\mathrm{CO}_{2}, \mathrm{CH}_{4}, \mathrm{NOx}$ etc. and raising attention due to extreme environmental issues. Biomass has huge potential as a feedstock for gasification, ethanol production, biochar production and other various fuel productions. However, the properties of biomass such as low bulk density, high moisture content, heterogeneous fibrous composition makes difficulties in energy generation processes. Also tar formation during the process of gasification increases the cost of gas separation. Paddy straw is one of the major 
agriculture waste produced in India. Paddy straw has high cellulosic contents that can be readily hydrolyzed into sugars for alcohol production. Paddy straw needs to be grind to 3 to $5 \mathrm{~mm}$ size for further processes (Chandra et.al, 2017). Size reduction is mechanical pretreatment in the form chopping, milling or grinding and can lead to efficient enzymatic hydrolysis of paddy straw (Ibrahim, 2012). However size reduction is energy intensive process. Energy consumption of size reduction depends on many factors including initial particle size, nature of composition, moisture content, material properties, total solid content, selection of machine etc. Fibrous composition of untreated paddy straw is shown in Table. 1. Hammer mill which is more efficient than other size reducing machineries consumes 34.8 to $45.3 \mathrm{kWh} / \mathrm{t}$ at feed rate of $2.5 \mathrm{~kg} / \mathrm{min}$ and operating speeds of $33.3-60 \mathrm{~Hz}$ for screen size of $3.2 \mathrm{~mm}$ (Bitra, 2009 and Himmel et. al., 1985). Fibrous composition of paddy straw makes it even more difficult to grind.

To make it more convenient for energy generating processes, paddy straw need pretreatment called torrefaction. Torrefaction of biomass, is a pretreatment through pyrolysis at temperatures in the range of 200 and $320{ }^{\circ} \mathrm{C}$. Torrefaction alters biomass properties to enhance the performance of combustion, gasification processes and most importantly ease in size reduction of biomass (Chew and Doshi, 2011).

Torrefaction before size reduction influences bio ethanol production process (Chaluwadi et al., 2018). It has been stated that, $351 \pm 5.49 \mathrm{mg} \mathrm{g}^{-1}$ of total sugars yield was obtained after torrefaction treatment at $220^{\circ} \mathrm{C}$ for $40 \mathrm{~min}$, representing a $60.68 \%$ increase compared with raw paddy straw (Singh R. K et al., 2019). Previous work of steamgasification showed that torrefaction decreases tar by $79 \%$ and fibrous characteristics of biomass. Brunauer-Emmett-Teller (BET) analysis showed that higher surface area for torrefied biomass char as compared to raw biomass char after devolatilization (Raut et al., 2016).

During torrefaction process, moisture content of biomass reduces and wood fiber structure of the material get destroyed (Kizuka, et al., 2019). It is stated that torrefied husks ignite faster (Pimchua et al., 2010). Torrefaction of biomass is an important preprocessing step which increases energy density (Singh et al., 2019). It was also claimed that torrefaction decreases oxygen/carbon ratio (Qing et.al, 2011).

Previous work on paddy straw has shown that energy yield decreases progressively from $75 \%$ to $62 \%$ with an increase in torrefaction temperature beyond $250{ }^{\circ} \mathrm{C}$ (Dhakate et al., 2018). Considering these findings, present study was designed to estimate effect of torrefaction on physio-chemical characterization and size reduction process of paddy straw.

Most of the researches have focused on its effect on fuel properties like proximate analysis, its porosity and its effect on the subsequent biofuel production process like ethanol production, biochar production, gasification process and quality analysis of fuel produced from torrefied biomass.

This study will focus on quantifying energy consumption in size reduction of torrefied paddy straw.

\section{Materials and Methods}

Study involves estimation of physio-chemical properties and performance of size reduction process of raw and torrefied paddy straw. Fig. 1 shows the flow chart of operations involving the present study. 
Physio chemical properties of untreated and torrefied paddy straw

The calorific value is indicator of the energy contained in the substance. The calorific value of paddy straw was determined by using Bomb calorimeter method recommended by the Indian standards Institution (IS: 13591959). The raw biomass was analyzed for moisture content using hot air oven at $105 \pm 5^{\circ} \mathrm{C}$ for 24 hours. The same sample placed in weighed crucible (diameter $2.5-3.5$ $\mathrm{cm}$, capacity $10-20 \mathrm{ml}$ ) with close fitting lid having bent for escape of volatile matter and kept in muffle furnace maintained at $925 \pm 20$ ${ }^{0} \mathrm{C}$. After heating exactly for 7 minutes crucible was taken out and cooled down rapidly by placing in a cold iron plate and then transferred warm crucible to desiccator to bring it to room temperature. After taking final weight of sample, volatile matter was calculated. Ash content was determined in the muffle furnace at a temperature of $550{ }^{0} \mathrm{C}$ for 1 hour. The procedure was repeated until no variation in the weight was observed. Fixed carbon was estimated as remaining part expelling volatile matter, moisture content and ash content. Bulk density of ground raw paddy straw and paddy straw torrefied at different temperature was measured.

\section{Detemination of Cellulose, hemicelluloses and lignin}

Hemicellulose content of paddy straw was measured after determining neutral detergent fiber (NDF) and acid detergent fiber (ADF). Hemi-cellulose was obtained by subtracting ADF from NDF of raw and treated paddy straw. Cellulose and lignin were calculated after determining acid detergent lignin (ADL). The previous acid detergent fiber (ADF) residue mat was covered with cold solution of $72 \% \mathrm{H}_{2} \mathrm{SO}_{4}$ Filled in crucible. After $3 \mathrm{~h}$, suction was applied to wash the contents of the crucible with hot distilled water to neutral
$\mathrm{pH}$ paper and followed by heating at $100^{\circ} \mathrm{C}$ in hot air oven and weighed. The above crucible was heated at $550{ }^{\circ} \mathrm{C}$ in muffle furnace for 3 hour for lignin content and weighed. Percent loss of weight in both the process was calculated for cellulose and lignin.

\section{TG Analysis}

To predict combustion behavior raw paddy straw was analyzed using Thermo gravimetric analyzer (TGA). This analysis gave the trend of combustion with respect to time and temperature. A small quantity of each paddy straw were taken and loaded in analyzer consisted of a high- precision balance with a pan (generally platinum). The pan was placed in a small electrically heated oven with a thermocouple to accurately measure the temperature. An inert gas, nitrogen was purged to prevent oxidation or other undesired reactions. A computer was used to control the instrument. The graph showing trend of loss of weight with respect to time was collected. For determination of torrefaction temperature, thermo gravimetric analysis of paddy straw was carried out to explore the thermal behavior of paddy straw with respect to temperature and time. From the TGA curve shown below, Temperature and time for torrefaction was decided. Light volatile matter starts escaping from paddy straw at $250^{\circ} \mathrm{C}$ as shown in Fig. 2. Also as torrefaction raises from beyond 250 to $300^{\circ} \mathrm{C}$, calorific value of biomass decreases. (Tumuluru et al., 2012 and Yan et al.,2009) Therefore torrefaction temperature is should be determined by observing thermal degradation of paddy straw with other parameters of like time and temperature.

\section{Torrefaction of paddy straw}

Paddy straw was collected from area of Ludhiana, India. Raw paddy straw was chopped with hand chopper with a view of 
getting 2-3 cm chopped biomass for the process of torrefaction. The biomass was weighed before it was filled in the vessel. Torrefaction of biomass was performed in the oven. Once the torrefaction temperature i.e., $250{ }^{\circ} \mathrm{C}$ was attained in the reactor, biomass kept in the oven for time duration of 20 and 30 min for torrefaction followed by natural cooling to ambient temperature. A grinder with a capacity of 3 horse power motor was used for grinding of raw and paddy straw torrefied at $250{ }^{\circ} \mathrm{C}$ at 20 and 30 minutes. Energy required for grinding these samples was calculated on the basis of time required for grinding.

\section{Effect of torrefaction on weight, mass and energy}

Weight loss, mass yield and energy yield considering weight loss and change in calorific value of raw paddy straw after torrefaction at both duration were calculated on percentage basis. Mass and energy yield was calculated as ratio of mass and calorific value of paddy straw after torrefaction to that of raw paddy straw on percent basis respectively.

\section{Weight loss (\%) \\ Mass of paddy - Mass of torrefied \\ Straw products}

Mass of paddy straw.............

\section{Particle Size Analysis}

Once grinding was done, sieve analysis of ground paddy straw was carried out in three replications of each treatment. Both ground untreated and torrefied samples of paddy straw were sieved for particle size analysis in different mesh size of 1.8, 3.55, 7.04,1.04, 2.88 and $4 \mathrm{~mm}$. Sieve shaker operated for 2 min for each sample and results were compared. Uniformity of particles of ground paddy straw can be assessed by calculation of a gradation index or uniformity coefficient from particle size distribution curve. Uniformity coefficient $\left(\mathrm{C}_{\mathrm{u}}\right)$ is a numerical measure to help interpret the distribution of particle sizes. Larger gradation indices indicate a less uniform material while smaller values indicate a more uniformity. These gradation indices employ the Dxx approach used for sand size analysis. From above graph, gradation index (D60/D10) was calculated for three treatments and shown in Table.3. The D60/D10 gradation index is obtained by dividing the D60 value (i.e. the grain diameter where $60 \%$ of the particles are smaller) by the D10 value (i.e. the grain diameter where only $10 \%$ of the particles are smaller).

\section{Cutting force}

Cutting force for untreated and torrefied paddy straw was estimated using Food Texture analyzer having load capacity of $50 \mathrm{~kg}$. A 50 $\mathrm{mm}$ wide knife type cutting probe having 0.6 $\mathrm{mm}$ thickness was used at the speed of $4 \mathrm{~mm}$ per second and operated at $8 \mathrm{~mm}$ of compression distance. Cutting force was measured for ten replicates of each sample and interpreted graphs in computer system were collected and compared.

\section{Results and Discussion}

\section{Physiochemical properties of paddy straw}

Calorific value of untorrefied and torrefied paddy straw at $250{ }^{\circ} \mathrm{C}$ for 20 and 30 minutes was found inversely proportional to moisture content. Proximate analysis was carried out to find out change in moisture content, volatile matter, ash content and fixed carbon after torrefaction at $250{ }^{\circ} \mathrm{C}$ temperature for different duration and presented in Table. 2. Due to removal of moisture, calorific value increased and therefore energy yield of paddy straw was also increased. It was observed that 
structure of paddy straw got shrinkage due to reduction of moisture and volatile matter. The straw having round cross section turned flat and compact after torrefaction which increased its energy density. Fig. 3 shows reduction in Bulk density of untreated paddy straw after torrefaction is due to its shrinkage of individual paddy straw.

The yellowish colour turned into brown and darker with the torrefaction duration. The morphological changes in paddy straw before and after torrefaction have shown in Fig. 4.

\section{Torrefaction of paddy straw}

Torrefaction was carried out and its effect on its morphology, weight, mass and energy was estimated. Fig. 5 shows that weight loss, mass yield and energy yield of paddy straw after torrefaction for 30 minute are higher than that of for 20 minutes. Paddy straw torrefied for 20 and 30 minutes had weight loss of 10.14 and $15.8 \%$, mass yield of 89.86 and $84 \%$ and energy yield of 92.56 and $87.46 \%$ respectively.

\section{Energy consumption in grinding}

Results obtained from Energy consumption calculations are presented in Fig. 6 which shows that energy required for grinding torrefied paddy straw increased with torrefaction duration. Energy consumption required in size reduction of raw paddy straw, paddy straw torrefied for 20 and 30 minues at $250{ }^{\circ} \mathrm{C}$ was $0.25,0.21$ and $0.16 \mathrm{kWh} / \mathrm{kg}$ respectively.

This change in enrgy requirement is due to alteration in physical properties of paddy straw after expose to temperature intensity. Untorrefied material required $20 \%$ and $36 \%$ more energy for size reduction than paddy straw torrefied at $250{ }^{\circ} \mathrm{C}$ for 20 and 30 minutes respectively.

\section{Particle size analysis}

Table. 3 is showing the results of sieve analysis of untorrefied paddy straw, paddy straw torrefied at $250{ }^{\circ} \mathrm{C}$ for $20 \mathrm{~min}$ and 30 min respectively. The particle size distribution curve showing cumulative percentage passing through the different sieves of sieve shaker. As shown in Fig. 7 and Table 4, the material torrefied for 20 minutes has gradation index 3.42 that is greater than rest of two treatments which mean it has less uniformity than rest of the treatments. Whereas, for untorrefied paddy straw, its gradation index was estimated 1.7 indicating its uniformity is higher having 0.95 $\mathrm{mm}$ diameter corresponding to $60 \%$ finer particle size of paddy straw. Untreated paddy straw has effective size (D10) $0.56 \mathrm{~mm}$ where as torrefied samples has finer effective size 0.22 and $0.18 \mathrm{~mm}$ respectively. This indicates that torrefaction of paddy straw for higher duration resulted in finer effective size because of change in the physical structure due to exposure of high temperature to the paddy straw.

\section{Cutting force}

Particle size analysis and energy consumption in size reduction of untreated and torrefied paddy straw can be supported by estimation of their cutting force requirement. The texture analyzer produced graph of cutting force against time shown in Fig.8. Paddy pod comprises various size of straws. The data of cutting force required to cut each sample shown that maximum cutting force required for untreated paddy straw was $2.9 \mathrm{~kg}$ and average cutting force required is $2.18 \mathrm{~kg}$ while maximum cutting force for paddy straw after torrefaction for 20 minutes and 30 minutes was 1.7 and $0.55 \mathrm{~kg}$ respectively and average cutting force for both samples was 1.31 and $0.44 \mathrm{~kg}$ respectively. This analysis gives clear indication of weakening of structure of paddy straw with respect to the torrefaction duration. 
Table.1 Paddy straw physical composition

\begin{tabular}{|c|c|c|c|}
\hline & Hemi cellulose, $\%$ & Cellulose, \% & Lignin, \% \\
\hline $\begin{array}{c}\text { Paddy } \\
\text { straw }\end{array}$ & 45 & 27 & 15 \\
\hline
\end{tabular}

Table. 2 proximate analysis of raw and torrefied paddy straw

\begin{tabular}{|c|c|c|c|c|}
\hline Sr. No. & Particulars & $\begin{array}{c}\text { Untorrefied } \\
\text { paddy straw }\end{array}$ & $\begin{array}{c}\text { paddy straw } \\
\text { torrefied at 250 } \\
\text { 'C for 20 min }\end{array}$ & $\begin{array}{c}\text { paddy straw } \\
\text { torrefied at } \\
\mathbf{2 5 0} \mathbf{C} \text { for 30 } \\
\text { min }\end{array}$ \\
\hline $\mathbf{1}$ & Moisture content, \% & 7 & 4 & 3.88 \\
\hline $\mathbf{2}$ & Volatile matter, $\%$ & 65 & 62 & 60 \\
\hline $\mathbf{3}$ & Ash content, $\%$ & 17 & 18.3 & 20 \\
\hline $\mathbf{4}$ & Fixed Carbon, $\%$ & 11 & 15.7 & 16.12 \\
\hline $\mathbf{5}$ & Calorific Value, $\mathrm{kCal} / \mathrm{kg}$ & 3456 & 3560 & 3590 \\
\hline
\end{tabular}

Table. 3 Seive analysis of ground paddy straw and paddy straw after torrefaction at $250{ }^{\circ} \mathrm{C}$ for 20 and 30 minutes

\begin{tabular}{|c|c|c|c|c|}
\hline Seive No & Sieve size & $\begin{array}{c}\text { Untorrefied } \\
\text { paddy straw }\end{array}$ & $\begin{array}{c}\text { paddy straw } \\
\text { torrefied at } \\
\mathbf{2 5 0} \mathbf{C}^{\circ} \mathbf{C} \text { for 20 } \\
\text { min }\end{array}$ & $\begin{array}{c}\text { paddy straw } \\
\text { torrefied at } \\
\mathbf{2 5 0} \mathbf{C}^{\circ} \text { for 30 } \\
\text { min }\end{array}$ \\
\hline $\mathbf{5}$ & 4 & 3.51 & 3 & 0 \\
\hline $\mathbf{4}$ & 2.88 & 7.04 & 2.69 & 1.31 \\
\hline $\mathbf{3}$ & 1.04 & 27.78 & 12.65 & 11.25 \\
\hline $\mathbf{2}$ & 0.704 & 7.3 & 19.5 & 19.1 \\
\hline $\mathbf{1}$ & 0.355 & 0.02 & 9.52 & 8.93 \\
\hline Pan & 0.18 & 0.29 & 4.42 & 2.6 \\
\hline Sum & & 45.94 & 51.78 & 43.19 \\
\hline
\end{tabular}

Table.4 Gradation index of ground paddy straw and paddy straw after torrefaction

\begin{tabular}{|c|c|c|c|}
\hline Treatment & D10 & D60 & $\begin{array}{c}\text { Gradation } \\
\text { index } \\
\text { (D60/D10) }\end{array}$ \\
\hline $\begin{array}{c}\text { Paddy straw torrefied at } \mathbf{2 5 0}^{\circ} \mathbf{C} \text { for } \mathbf{2 0} \\
\text { min }\end{array}$ & 0.223 & 0.704 & 3.16 \\
\hline $\begin{array}{c}\text { Torrefied Paddy straw at } \mathbf{2 5 0}^{\circ} \mathbf{C} \text { for } \mathbf{3 0} \\
\text { min }\end{array}$ & 0.18 & 0.616 & 3.42 \\
\hline Untreated Paddy straw & 0.564 & 0.956 & 1.70 \\
\hline
\end{tabular}


Fig.1 Flow chart of torrefaction experiment

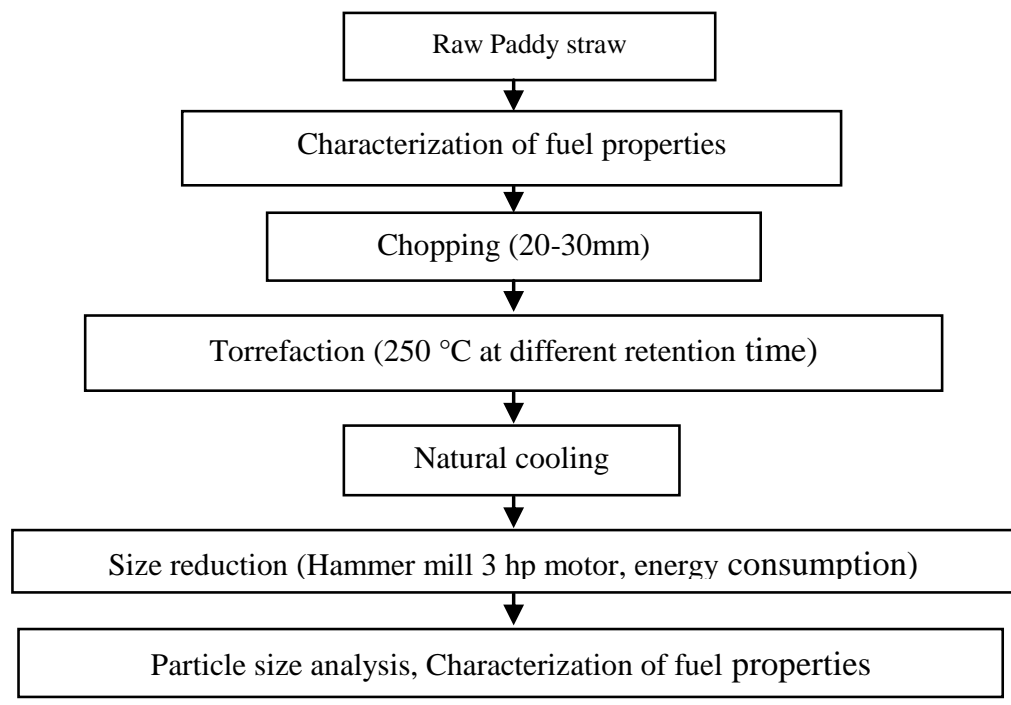

Fig.2 Thermo-gravimetric analysis of paddy straw

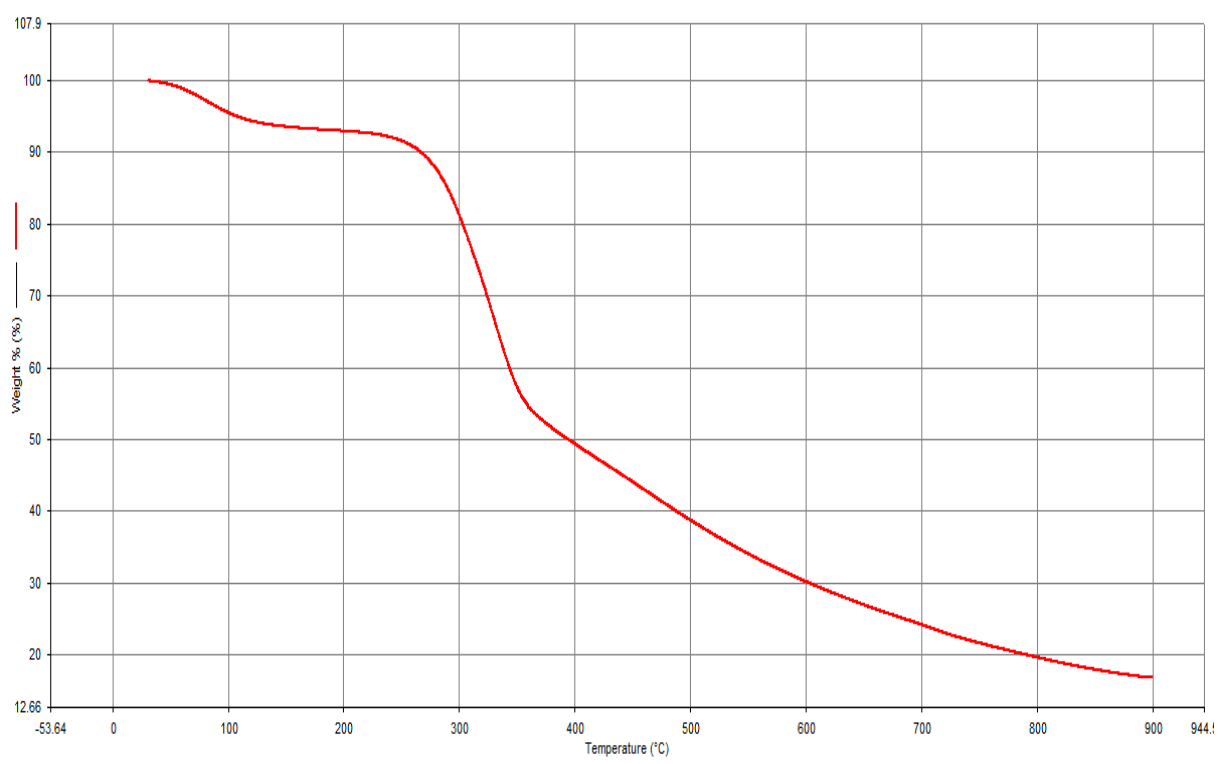


Fig.3 Bulk density of torrefied and untorrefied ground paddy straw

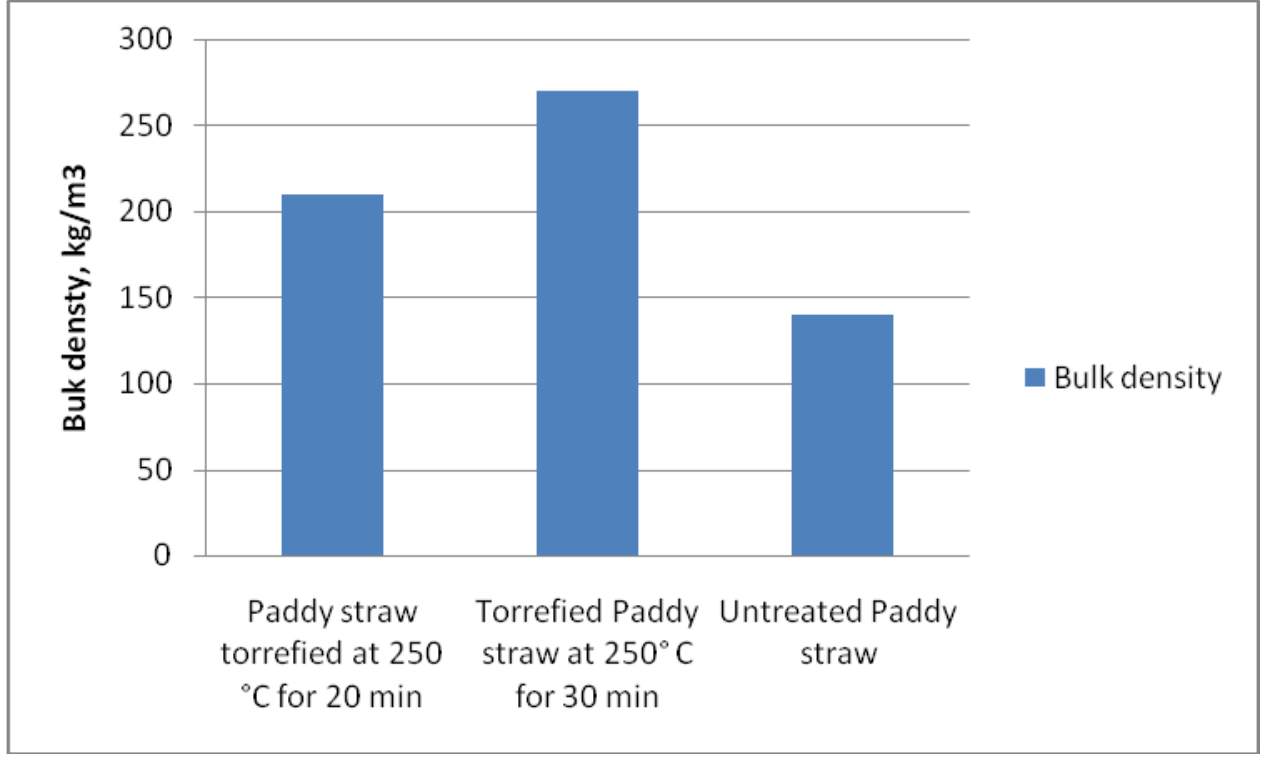

Fig.4 Morphological appearance of paddy straw before and size reduction
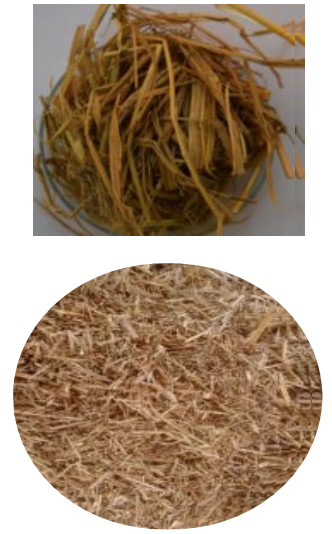

Paddy straw
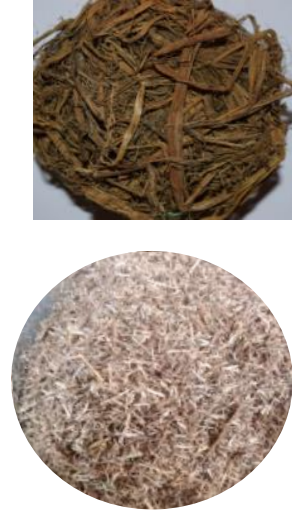

Paddy straw torrified at $250{ }^{\circ} \mathrm{C}$ for $20 \mathrm{~min}$
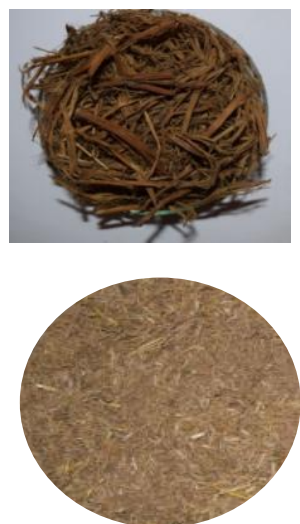

Paddy straw torrified at $250{ }^{\circ} \mathrm{C}$ for $30 \mathrm{~min}$ 
Fig.5 Effect of torrefaction on weight, mass and energy content of paddy straw after torrefaction

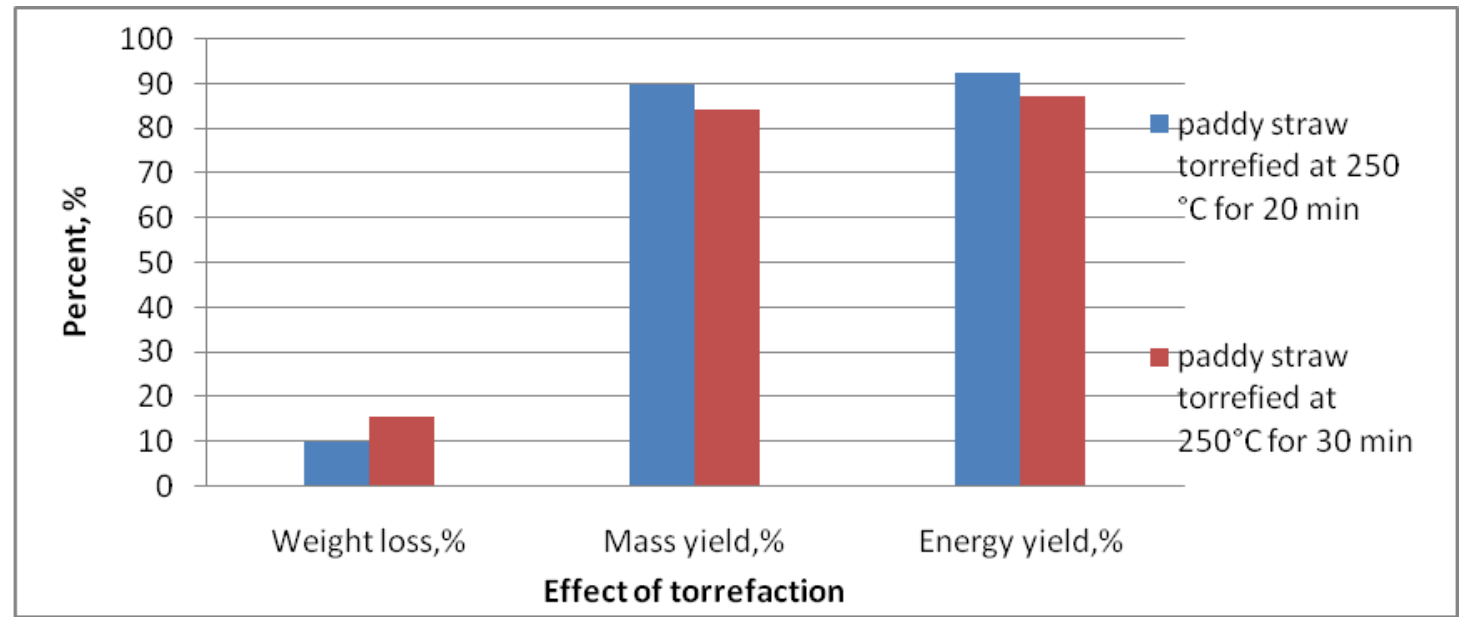

Fig.6 Energy consumption in size reduction of raw and torrefied paddy straw

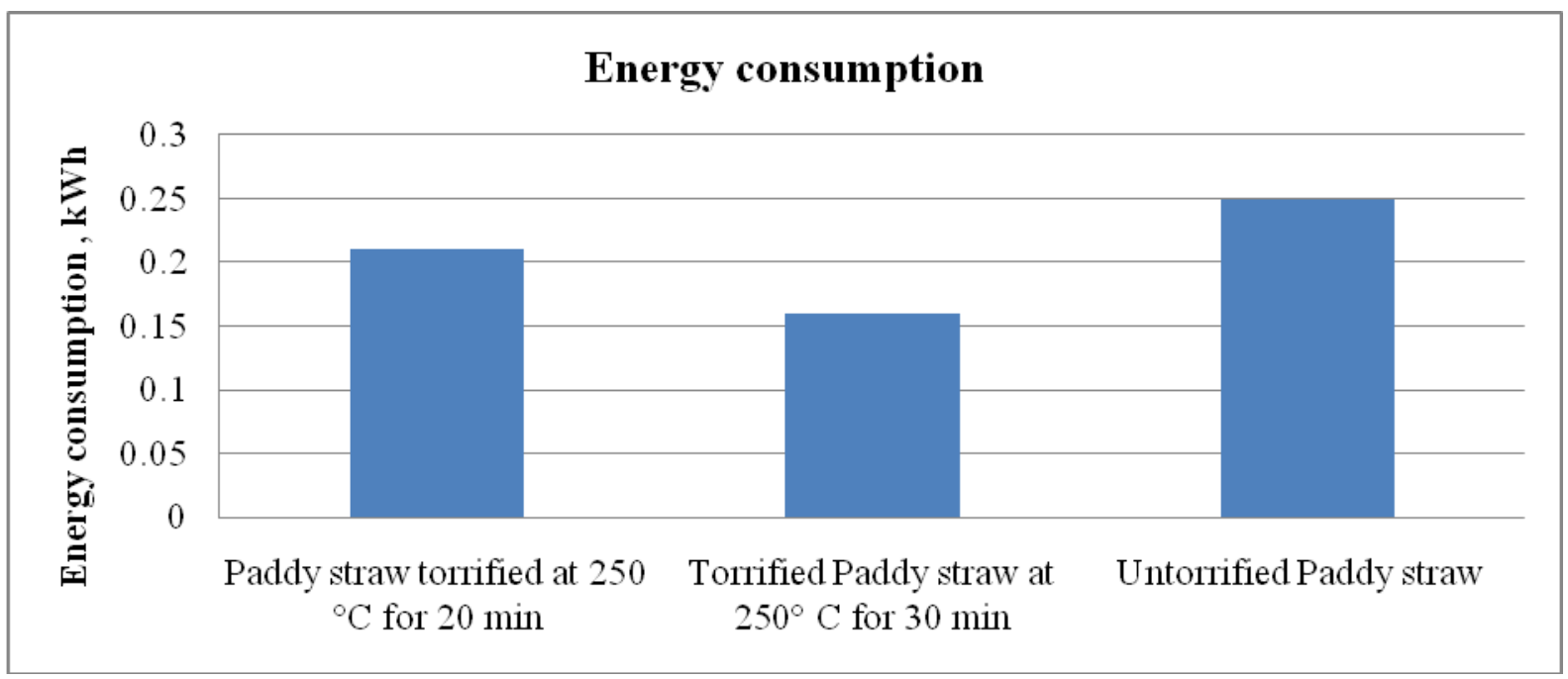


Fig.7 Particle size analysis of ground untorrefied and torrefied paddy straw

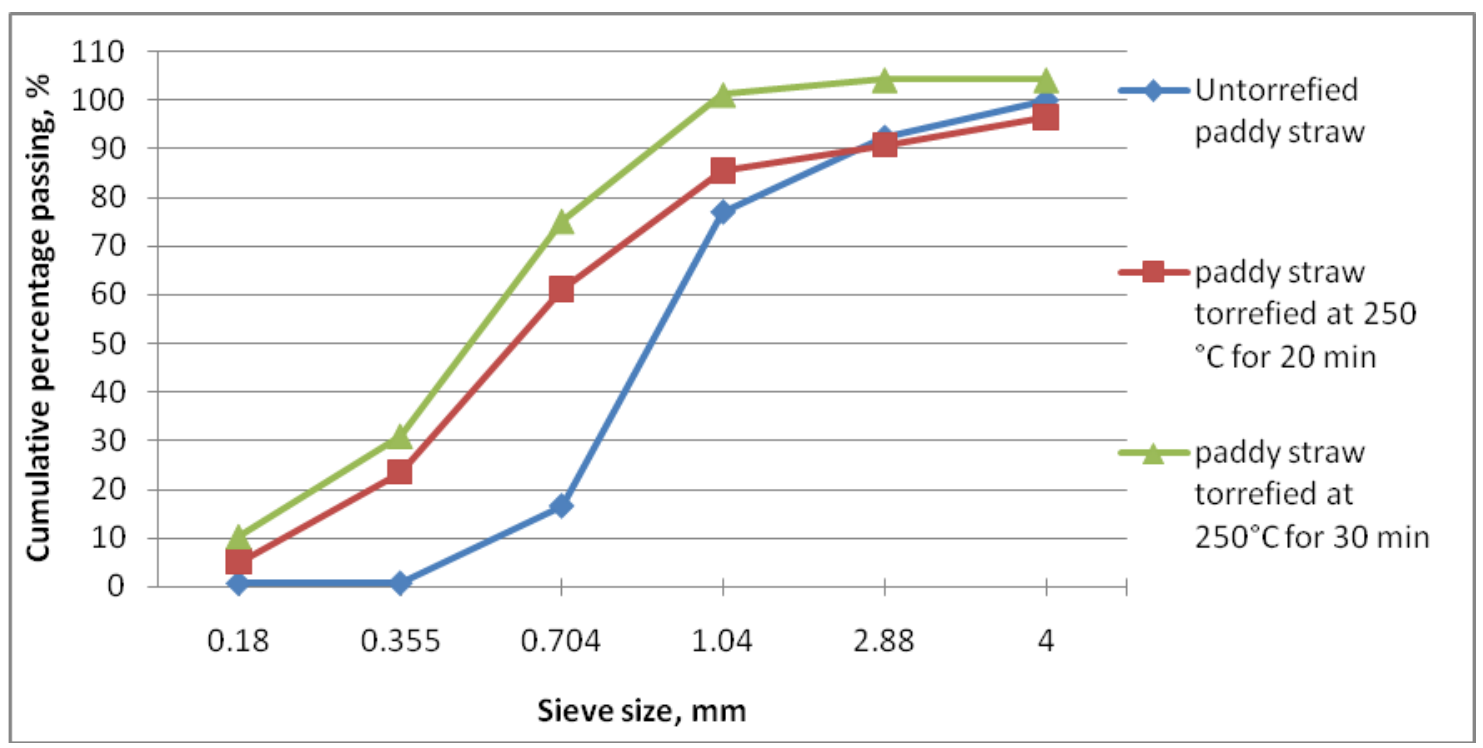

Fig.8 Graphical representation of cutting force required to cut paddy straw and paddy straw torrefied at $250^{\circ}$ for 20 minutes and 30 minutes

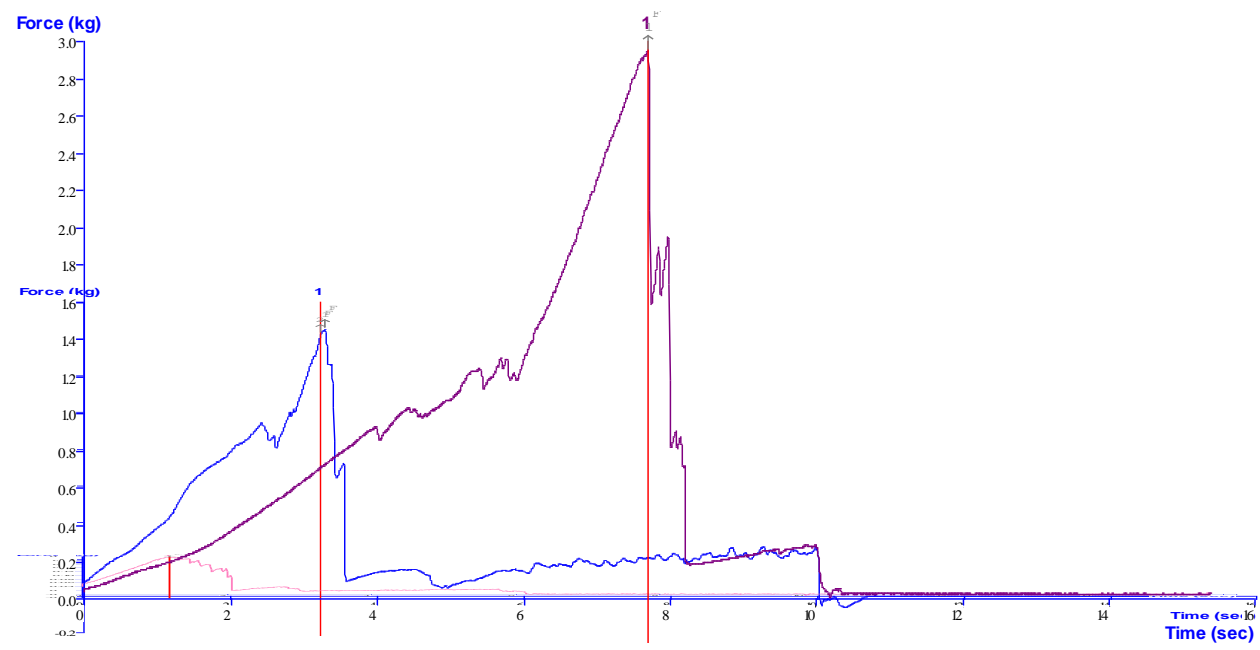

Untreated paddy straw required $80 \%$ and 40.4 $\%$ more cutting force than that of paddy straw torrefied at $250{ }^{\circ} \mathrm{C}$ for 30 minutes and 20 minutes respectively.

From this study, it was observed that physiochemical properties of paddy straw alters with extended duration of torrefaction which were useful in its size reduction and bio fuel generation. Due to change in physical properties, torrefied paddy straw require higher cutting force and hence energy in grinding than untorrefied material. There is increase in bulk density and energy yield after torrefaction. Size reduction produces finer effective size of paddy straw with the extending duration of torrefaction at $250{ }^{\circ} \mathrm{C}$. It was found that torrefaction treatment has a 
considerable effect on the uniformity of particle size of the biomass during the process of grinding. Torrefaction has potential to reduce cost of operation and to create more options for utilization of paddy straw.

\section{Acknowledgement}

All the authors are very thankful to ICARCentral Institute of Agricultural Engineering, Bhopal, India and College of Agricultural Engg and Technology, Punjab Agricultural University, Ludhiana, Punjab for providing all the necessary facilities during the work.

\section{References}

Alexandre Govin, Vincent Repellin, Mathieu Rolland, Jean-Luc Duplan. 2009. Effect of torrefaction on grinding energy requirement for thin wood particle production. XII Congrès de la Société Françaisede Génie des Procédés Pour relever les défis industriels du XXI siècle A la croisée des Sciences et des Cultures, Marseille, France. hal-00462339.

Bitra VSP, Womac AR, Chevanan N, Miu PI, Igathinathane C, Sokhansanj S. Direct mechanical energy measured of hammer mill comminution of switchgrass, wheat straw, and corn stover and analysis of their particle size distributions. Powder Technology, 2009; 193: 32-45.

Chaluvadi, S., Ujjwal, A. \& Singh, R.K. Waste Biomass Valor (2018). Waste and Biomass Valorization. https://doi.org/10.1007/s12649-0180389-4. 1-11.

Chandra, R., Trivedi, A., Jha, B., Verma, A. R. and Vijay, V. K. 2017. Energy Generation from Paddy Straw: An Analysis of Bioenergy Models. Akshay Urja, 22-27.
Chew, J.J. \& Doshi, V., 2011. "Recent advances in biomass pretreatment Torrefaction fundamentals and technology," Renewable and Sustainable Energy Reviews, Elsevier, vol. 15(8): 4212-4222.

Dhakate, S. R., Pathak, A. K., Jain, P., Singh, M., Singh, B. P., Subhedar, K. M., Sharda S. S. and Seth R. K. 2018. Rice straw biomass to high energy yield biocoal by torrefaction: Indian perspective, Current Science, VOL. 116, NO. 5, 831-838.

Himmel M., Tucker M., Baker J., Rivard C., Oh K., Grohmann K., 1985, Comminution of biomass: hammer and knife mills. Biotechnology and Bioengineering Symposium, 15, 3958.

Ibrahim, H. A. H. 2012. Pretreatment of straw for bioethanol production. Energy Procedia 14. 542 - 551.

Jaya Shankar Tumuluru, J. Richard Hess, Richard D. Boardman, Christopher T. Wright, Tyler L. Westover. 2012. Formulation, Pretreatment, and Densification Options to Improve Biomass Specifications for Co-Firing High Percentages with Coal. Industrial Biotechnology 8:3, 113-132.

Kizuka, R., Ishii, K., Sato, M. and Fujiyama, A. 2019. Characteristics of wood pellets mixed with torrefied rice straw as a biomass fuel, International Journal of Energy and Environmental Engineering. Volume 10, (3) : 357365.

Manoj K. Raut, Prabir Basu and Bishnu Acharya (2016)," The Effect of Torrefaction Pre-Treatment on the Gasification of Biomass " International Journal of Renewable Energy and Biofuels, Vol. 2016 (2016), Article ID 823723, DOI: $10.5171 / 2016.823723$

Pimchuai, A., Dutta, A. and Basu, P. (2010) Torrefaction of Agriculture Residue To 
Enhance Combustible Properties. Energy Fuels 2010 24, 9: 4638-4645. https://doi.org/10.1021/ef901168f

Qing, C. JinSong, Z. BingJun, L. QinFeng, M. \& ZhongYang, L. (2011) Influence of torrefaction pretreatment on biomass gasification technology. Chinese science bulletin, Vol.56 No.14: 14491456. doi: 10.1007/s11434-010-4292$\mathrm{Z}$.

Singh, R K, Sarkar, A. and Chakraborty, J. P., 2019. "Effect of torrefaction on the physicochemical properties of pigeon pea stalk (Cajanus cajan) and estimation of kinetic parameters," Renewable Energy, Elsevier, vol. 138(C), pages 805-819.

Yan W, Acharjee TC, Coronella CJ, Vasquez VR. Thermal pretreatment of lignocellulosic biomass. Environ Prog Sustain Energ 2009;28(3):435440. Crossref, Google Scholar

\section{How to cite this article:}

Swapnaja K. Jadhav, H. Wakudkar, Manvendra Bhardwaj and Rajesh Soni. 2020. Effect of Torrefaction on Physio-Chemical Properties of Paddy Straw and its Size Reduction. Int.J.Curr.Microbiol.App.Sci. 9(01): 7-18. doi: https://doi.org/10.20546/ijcmas.2020.901.002 